\title{
COMPARISON OF INDEX OF ABILITY TO WORK (ICT) AMONG WORKERS OF DAY AND NIGHT FIXED WORK SHIFT
}

\author{
Luciana Duarte Satler de Oliveira \\ Physiotherapist specialist in Ergonomics / FUMEC \\ (31)9152-1394 - Belo Horizonte, $M G$ \\ Email:1ucianasatler@hotmail.com \\ Sarina Occhipinti Magalhães \\ Doctor specialist in Ergonomics / UFMG \\ (31)92090259 - Belo Horizonte, $M G$ \\ Email: sarina.om@gmail.com
}

\begin{abstract}
The aim of this paper was to investigate the work ability of employees within a multinational corporation specialized in supplying automated production lines and maintenance of industrial assets and the relation between work shifts and the work ability. This is a descriptive comparative study conducted in the company, with a sample of 776 maintenance workers. We used the Work Ability Index (WAI) to assess their ability to work. The study subjects were young adults, all male, around 37 years old, divided into $53.6 \%$ in the fixed shift and $46.4 \%$ in rotating shifts. From the results, it can be concluded that workers in general have good work ability, but when divided into shifts, better results are found in the group of rotating shift workers. Further study should be conducted to investigate whether the shift interferes on the outcome of WAI.
\end{abstract}

Keywords: work ability, working conditions, health worker's day shift and night shift

\section{INTRODUCTION}

The competitive market and their own production processes requires companies a better allocation of labor, leading them to distribute the work schedule in various ways. Split work in shifts during the day or night is a very common strategy to optimize space, time, production flow and product cost. The use of the work divided into shifts is essential for companies providing support services to other companies such as machine maintenance, building maintenance, cleaning and others. Support companies must increase their productive force in moments when the main company's production is decreased or absent. This study was conducted in a multinational engineering and management in industrial assets, in the automobile industry in Betim, Brazil. The aim of this study was to evaluate whether there is any impact on the physical and mental health among employees who work in day shifts compared with those who work the night shift. For the research was chosen a questionnaire that measures the level of the Work Ability, developed in Finland by the working group of the Institute of Occupational Health (Tuomi, Kaija et al.). The ICT is a selfassessment and self-administered instrument. It is known that work capacity is the basis of well-being of the individual who been affected by factors such as lifestyle and work environment can be influenced by the very activity of the individual (Tuomi et al.1997).
So, it is believed that the quality of life in which we find the employee may bring about significant positive or negative effect on work capacity.

The work in shifts is often suggested as a possible cause of physiological and psychological disorders and distress in social and family life, damaging the professional in your life, leading to physical and mental exhaustion of the employee, reflecting on their performance and quality of life. According to Frida Fisher, 1997, the health

disorders are manifested by insomnia,irritability, excessive sleepiness, continuous fatigue and malfunctions of the digestive and cardiovascular systems. Interference in social and family relations are translated by the absence of the father,mother, friend, boyfriend, daughter, and others; in times of commemorative dates,weekends and holidays. The consequences of these disturbances are observed at short, medium and long term, both in quality of life of workers and their family, workers health, the quality of care, safety at work, and consequently the capacity to work.

The capacity to work within the area of occupational health can be conceptualized according to Tuomi et al. (1997) as how well is or will be, a worker at present or in the near future, and how capable he can perform his job, according to the requirements, of their health condition and their physical and mental capacity. Otherwise, one can conceptualize the capacity to work, starting from the meaning of the 
word "capacity" that is the quality that a person must satisfy for certain purpose and the word "work " that is the coordinated activity of physical and / or intellectual property rights required to perform any task, service or enterprise (FERREIRA, 2000). Therefore, work capacity may be the physical and / or mental quality with which man develops his work. The Index of the Work Ability - ICT - includes self-assessment of the employee about their health and work capacity taking predictive character. The instrument allows the diagnosis of loss of capacity to precocious work so that prevention programs, maintenance and promotion of health help in the occupational health of workers and should be used in Occupational Health Services. The final score of the points is between $\quad 7$ and 49 points and "[...] portrays the own concept of a worker about its capacity to work."

\begin{tabular}{|l|l|l|}
\hline Points & $\begin{array}{l}\text { Work } \\
\text { ability }\end{array}$ & Measures Objectives \\
\hline $7-27$ & Low & Restore the ability to work \\
\hline $28-36$ & Moderate & Improving the ability to work \\
\hline $37-43$ & Good & Improving the ability to work \\
\hline $44-49$ & Excellent & Keep the capacity to work \\
\hline
\end{tabular}

Figure 1 - Characteristics of the Index of the Work Capacity

The studies that are endorsing the importance of the Index of the Work Ability (ICT) had as subjects workers aging in municipal occupations, in 1981 and 1992, with the goal of seeking, among workers, who were approaching retirement age and also the significance of maintaining their health and work capacity. The information was based on the model of stress tension derived from the theory of job stress and lifestyle, health and aging from the point of view of the World Health Organization. The attention was focused on changes in work, lifestyle, health, symptoms of stress, the capacity to work and the causes of changes. The changes were examined by age, gender, job satisfaction and job profile. these promotion of health and work capacity was studied by examining factors associated with well being and the improvement of health and work ability. The meanings for prevention were searched by the study of factors associated with deteriorating health and work capacity. The study showed that the capacity for the work of many Finnish workers was deteriorated prematurely. The decline in work capacity reflected in diseases and symptoms, the decline of functional capacity, retirement due to invalidity or precocious and often, in mortality before the age of retirement. This result may represent the influence of the aging process at work.
Aging can cause difficulties in performing tasks. The damage associated with the physical demands may reflect in the general health. An increase in muscular working is associated with the decline of work capacity. Physical demands diminish the capacity for work, influencing the lives of workers. Few workers continued working during the search.

Given the above, the study aims to compare the work capacity of workers of day and night shift for an engineering and management in industrial assets multinational.

\section{MATERIAL E METHOD}

The population consisted of 1202 workers in the role of maintainer (production sector)and administrative assistants (office sector) of which 875 were fixed day shift workers and 327, fixed shift overnight. The day shift worker comprises two groups: one who works from 8 to 17:30 hours and another that has his journey from 6 to 14:48 hours. The night work on the other hand is divided into two shifts: one from 15:48 to 01:09 hours and another from 22:54 to 6 hours. We used the index of the Work Capacity - ICT for being a self-applicable and with appropriate methodology to the goals as well as another instrument with demographic

data, lifestyle and leisure, to characterize the population. The instruments were applied during the period from February to December of 2009 during the execution of periodic examinations at the company. It was used the free and informed consent being guaranteed to research subjects that nonparticipation would not cause any damage in relation to their work. The data were tabulated with the help of Microsoft Excel 2000 for ICT and relay studied.

\section{RESULTS}

Data are presented in a simple way, starting with the first part of the instrument in which are raised personal and professional aspects and in a complex shape, represented by the correlations of the ones of relay considered more important.

Table 1 shows the distribution of population according to socio demographic characteristics. There is a majority of male workers (93.3\%); the age group with the highest frequency was the one with more than 40 years $(47.5 \%), 72.8 \%$ of the examined workers conduct their work in turn daytime. 


\begin{tabular}{|l|l|rc|}
\hline & Categories & \multicolumn{2}{|l|}{ Workers } \\
& & N & \% \\
\hline Gender & M & 1121 & 93,3 \\
& F & 81 & 6,7 \\
\hline Age (years) & Up to 29 & 277 & 23,1 \\
& From 30 to 39 & 353 & 29,4 \\
& Above 40 & 572 & 47,5 \\
\hline Shift & Day & 875 & 72,8 \\
& Night & 327 & 27,2 \\
\hline
\end{tabular}

Table 1 - Distribution of workers according sociodemographic characteristics.

Table 2 correlates the shifts with the ICT.

\begin{tabular}{|l|l|l|l|l|}
\hline & \multicolumn{4}{|l|}{ ICT } \\
\hline Shift & $\begin{array}{l}\text { Low } \\
\%\end{array}$ & $\begin{array}{l}\text { Moderate } \\
\%\end{array}$ & $\begin{array}{l}\text { Good } \\
\mathbf{\%}\end{array}$ & $\begin{array}{l}\text { Excellent } \\
\%\end{array}$ \\
\hline Day & 0,0 & 0,1 & 7,4 & 92,5 \\
\hline Night & 0,0 & 0,6 & 5,2 & 94,2 \\
\hline
\end{tabular}

Table 2 - Distribution of workers of shift, according to the result of ICT.

Table 3 shows the distribution of workers by age group, related to the ICT score.

In night shift workers, the category of good ICT was more frequent in the age group above 40 years with $30.4 \%$, followed by those 30 to 39 years $(10 \%)$.

Already in night shift workers, the age group above 40 years was $9.8 \%$ of its population with good ICT followed of those of 30 to 39 years $(6.8 \%)$ and up to 29 years $(5.3 \%)$.

\begin{tabular}{|c|c|c|c|c|c|c|c|c|}
\hline \multicolumn{9}{|c|}{$\begin{array}{l}\text { INDEX OF CAPACITY TO WORK } \\
\text { NIGHT SHIFT } \\
\end{array}$} \\
\hline \multirow{2}{*}{$\begin{array}{l}\text { Age } \\
\text { Group }\end{array}$} & \multirow{2}{*}{\multicolumn{2}{|c|}{\begin{tabular}{|l|} 
Low \\
$\mathbf{N}$ \\
$\%$ \\
\end{tabular}}} & \multirow{2}{*}{\multicolumn{2}{|c|}{$\begin{array}{l}\text { Moderate } \\
\text { N } \%\end{array}$}} & \multirow{2}{*}{\multicolumn{2}{|c|}{$\begin{array}{l}\text { Good } \\
\mathbf{N} \\
\%\end{array}$}} & \multirow{2}{*}{\multicolumn{2}{|c|}{$\begin{array}{l}\text { Excellent } \\
\mathrm{N} \%\end{array}$}} \\
\hline & & & & & & & & \\
\hline $\begin{array}{ll}\text { Up to } \\
29\end{array}$ & 0 & $\mathbf{0 , 0}$ & 0 & $\mathbf{0}$ & 0 & $\mathbf{0}$ & 69 & 100 \\
\hline \begin{tabular}{l}
\multicolumn{2}{l}{$\begin{array}{l}\text { From } \\
30\end{array}$} \\
39
\end{tabular} & 0 & $\mathbf{0 , 0}$ & 0 & 0 & 9 & 10 & 81 & 90 \\
\hline $\begin{array}{l}\text { Above } \\
40\end{array}$ & 0 & $\overline{\mathbf{0 , 0}}$ & 2 & 1,2 & 51 & 30,4 & 115 & 68,4 \\
\hline
\end{tabular}

\begin{tabular}{|c|c|c|c|c|}
\hline \multicolumn{5}{|c|}{$\begin{array}{l}\text { INDEX OF CAPACITY TO WORK } \\
\text { DAY SHIFT }\end{array}$} \\
\hline $\begin{array}{l}\text { Age } \\
\text { Group }\end{array}$ & $\begin{array}{l}\text { Low } \\
\mathbf{N} \\
\%\end{array}$ & $\begin{array}{l}\text { Moderate } \\
\text { N } \%\end{array}$ & $\begin{array}{l}\text { Good } \\
\mathbf{N} \\
\%\end{array}$ & $\begin{array}{l}\text { Excellent } \\
\text { N } \%\end{array}$ \\
\hline
\end{tabular}

\begin{tabular}{|l|l|l|l|l|l|l|l|l|}
\hline $\begin{array}{l}\text { Up to } \\
\mathbf{2 9}\end{array}$ & 0 & $\mathbf{0 , 0}$ & 0 & $\mathbf{0}$ & 11 & $\mathbf{5 , 3}$ & 197 & $\mathbf{9 4 , 7}$ \\
\hline $\begin{array}{l}\text { From } \\
\mathbf{3 0} \text { to } \\
\mathbf{3 9}\end{array}$ & 0 & $\mathbf{0 , 0}$ & 0 & $\mathbf{0}$ & 18 & $\mathbf{6 , 8}$ & 245 & $\mathbf{9 3 , 2}$ \\
\hline $\begin{array}{l}\text { Above } \\
\mathbf{4 0}\end{array}$ & 0 & $\mathbf{0 , 0}$ & 1 & $\mathbf{0 , 2}$ & 39 & $\mathbf{9 , 7}$ & 364 & $\mathbf{9 0 , 1}$ \\
\hline
\end{tabular}

Table 3 - Distribution of workers according to the relation age group and the index of capacity to work.

It was also verified that $1.2 \%$ of night shift workers showed a moderate ICT compared with only $0.2 \%$ of workers in day shift.

\section{CONCLUSION}

In this study was evaluated the Index of Capacity for Work of 1202 workers in the role of maintainer (production sector) and administrative assistants (office sector) of which 875 were employees of day shift and 327 of night shift.

The average age of the population studied was 39 years being that the majority of workers (47.5\%) had age over 40 years.

From the results, it can be concluded that workers in general have a good capacity for work, but when divided into shifts, better results are fou nd in the group of workers in day shift. Further studies should be conducted to investigate whether the shift affects the result of ICT.

\section{BIBLIOGRAPHIC REFERENCES}

BÚRIGO, C.C.D. Qualidade de vida no trabalho: dilemas e perspectivas. Florianópolis: Insular, 1997.

COSTA, E.S.; MORITA, I.; MARTINEZ, M.A.R. Percepção dos efeitos do trabalho em turnos sobre a saúde e a vida social em funcionários da enfermagem em um hospital universitário do Estado de São Paulo. Cad. Saúde Pública, Rio de Janeiro, v.16, n.2, p.553-555, abr.-jun. 2000.

FERNANDES, E.C. Qualidade de vida no trabalho: como medir para melhorar. Salvador: Casa da Qualidade, 1996.

FERREIRA, A.B.H. Mini Aurélio século XXI: o minidicionário da língua portuguesa. Rio de Janeiro: Nova Fronteira, 2000.

FISCHER, F.M.; LIEBER, R.R.; BROWN, F.M. Trabalho em turnos e as relações com a saúde-doença. In MENDES, R. Patologia do trabalho. Rio de Janeiro: Atheneu, 1999.

MAURICE apud FISCHER, F.M. Trabalho em turnos: alguns aspectos econômicos, médicos e sociais. Rev. Bras. Saúde ocup, v. 9, n. 36, p.5-40, 1981.

TUOMI K, ILMARINEN J, JAHKOLA A, KATAJARINNE L, TULKKI A. Índice de capacidade para o trabalho. São Carlos: EDUFSCAR; 2005 